\title{
Dental Students' Perceptions about the Endodontic Treatments Performed Using NiTi Rotary Instruments and Hand Stainless Steel Files
}

\author{
Renata Castro MARTINS ${ }^{1}$ \\ Marília Oliveira Saraiva SEIJO ${ }^{2}$ \\ Efigênia Ferreira FERREIRA ${ }^{1}$ \\ Saul Martins PAIVA ${ }^{3}$ \\ Antônio Paulino RIBEIRO SOBRINHO²
}

\begin{abstract}
${ }^{1}$ Department of Community and Preventive Dentistry, ${ }^{2}$ Department of Operative Dentistry, ${ }^{3}$ Department of Pediatric Dentistry and Orthodontics, Dental School, UFMG - Universidade Federal de Minas Gerais, Belo Horizonte, MG, Brazil
\end{abstract}

\begin{abstract}
This study evaluated the perceptions of Brazilian undergraduate dental students about the endodontic treatments performed using NiTi rotary instruments and hand stainless steel. Data were collected using a questionnaire administered to undergraduate dental students enrolled in endodontic disciplines. The students were divided into 3 groups: G1, students who had treated straight canals with SS hand instruments; G2, students who had treated curved canals with SS hand instruments; and G3, students who had treated both straight and curved canals with NiTi rotary instruments. The number of endodontic treatments performed, types of treated teeth, students' learning, time spent, encountered difficulties, quality of endodontic treatment and characteristics of the employed technique were analyzed. There was a $91.3 \%$ rate of return for the questionnaires. Mandibular molars were the most frequently treated teeth, followed by maxillary incisors. The Kruskal-Wallis test showed no differences in learning $(\mathrm{p}=0.528)$ or in the characteristics of the technique employed $(\mathrm{p}=0.560)$ among the three groups. G3 students performed a greater number of endodontic treatments $(\mathrm{p}<0.001)$ in a smaller time $(p<0.001)$ than did G1 and G2 students. Difficulties were reported primarily by students in G2 and G3 compared with $\mathrm{G} 1$ ( $\mathrm{p}=0.048)$. The quality of endodontic treatments differed only between $\mathrm{G} 1$ and $\mathrm{G} 2$ ( $\mathrm{p}=0.045)$. The use of NiTi rotary instruments should be included in undergraduate dental curriculum, contributing to the increase of patients assisted and consequently to improve the clinical experience of the students.
\end{abstract}

Key Words: education, students, Endodontics, nickel-titanium, stainless steel.

\section{INTRODUCTION}

Dental students' perspectives on their educational experiences are an essential component of curriculum planning, they can direct program changes that enhance learning. The importance of this feedback is well supported; however, it has received little attention in dental school educational planning $(1,2)$.

Students consider dentistry one of the most difficult programs. In addition to its extensive program that requires dedication and financial resources, a number of factors, including clinical experience, constant ranking and comparing of students, teacher/student relationships, patient/student relationships, clinical application of theory, extracurricular opportunities and self-confidence levels, can influence significantly the way students perceive and experience their education (2-4).

Within the field of dentistry, Endodontics is considered an especially difficult and stressful discipline. Because of the anatomical diversity of root canals, the need to provide care to patients and the students' lack of self-confidence, several students do not feel adequately prepared for their assessments in the more difficult procedures, such as molar endodontic treatment. This insecurity may reflect insufficient clinical and didactic teaching in the dental curriculum (5).

Several debridement techniques have been proposed, but it remains a complex procedure that can be daunting for patients, clinicians and students. Stainless steel (SS) hand instruments used for root canal

Correspondence: Renata Castro Martins, Rua Carangola, 62/101, Santo Antônio, 30330-240 Belo Horizonte, MG, Brasil. Tel. +55-31-3293-2786. Fax:+55-31-3409-2472. e-mail: r.c.martins@uol.com.br 
shaping lack flexibility, which can result in procedural errors, such as transportation, ledges or perforations. Nickel-titanium (NiTi) alloys have become popular for endodontic files because of their lower modulus of elasticity compared with SS, which facilitates the use of these instruments in curved canals (6). These instruments include design variables that allow clinicians to perform shaping procedures more easily, quickly, and predictably (7). However, the introduction of NiTi rotary instruments to undergraduate training has met some resistance because of the risk of instrument fractures and the expensive infrastructure required $(8,9)$, despite several reports indicating low numbers of such complications $(7,10)$.

Students' perceptions of the instruments and techniques used for endodontic treatments must be collected to provide feedback about the quality of endodontic education. Therefore, the purpose of this study was to evaluate the undergraduate dental students' perceptions about the endodontic treatment performed using NiTi rotary instruments and SS hand files.

\section{MATERIAL AND METHODS}

Ethical approval was provided by the UFMG's Human Research Ethics Committee of, Brazil (Protocol \#0462.0.203.000-09). This cross-sectional study was conducted with a group of 126 undergraduate dental students enrolled in Endodontics disciplines during the second semester of 2009 at UFMG, Brazil. The dental undergraduate program has a curriculum that consists of 9 semesters and admits 144 new students annually (72 per semester). The Endodontics disciplines are taught during the fifth, sixth and eighth semesters of the program. During the fifth semester (Endodontics I), the students have their first contact with Endodontics (theory and preclinical and clinical classes) and their first opportunities to perform simple endodontic treatments (single-rooted and/or double-rooted teeth), with an average of $30 \mathrm{~h}$ of theory and $60 \mathrm{~h}$ for clinical training. During the sixth semester (Endodontics II), the students execute more difficult endodontic treatments (multirooted teeth), with $15 \mathrm{~h}$ for theory and $60 \mathrm{~h}$ for clinical training on average. In Endodontics I and II disciplines, the students use SS hand instruments (K-Flexofiles; Dentsply Maillefer, Ballaigues, Switzerland) and employ Oregon (11) and Buchanan techniques (12), respectively, to perform endodontic treatments. The Endodontics discipline offered in the eighth semester (Endodontics
III) is optional and includes a smaller number of undergraduate students than the required Endodontics disciplines in the fifth and sixth semesters. The students enrolled in this optional discipline use NiTi rotary instruments (ProTaper Universal; Dentsply Maillefer) and employ ProTaper technique (13) to perform endodontic treatments of molars and occasionally incisors, canines or premolars. These students have 15 $\mathrm{h}$ of theory and $60 \mathrm{~h}$ for practical training on average. Regardless of the instruments employed, the technique of choice is crown-down preparation.

For this study, the students were divided into 3 groups, according to the Endodontics discipline in which they were enrolled: G1 $(n=52)$ : Endodontics I; G2 ( $\mathrm{n}=62)$ : Endodontics II; G3 ( $\mathrm{n}=12)$ : Endodontics III.

All Endodontics disciplines include $4 \mathrm{~h}$ per week of clinical practice. The students of G1 and G2 worked in operator/assistant pairs and each student met a patient every 15 days until completing the endodontic treatment. The students of G3 worked alone and met a patient every week until completing the endodontic treatment.

An information sheet was provided to each student explaining the purpose of the study, that the study was completely confidential, that participation was voluntary and that no names would be used in the report. All students who agreed to participate signed an informed consent form.

A self-administered questionnaire consisting of 9 open-ended questions and multiple-choice items was used for data collection. The questionnaire was administered to undergraduate students in G1, G2, and G3 during final examinations at the end of the semester. Some questions required a box to be checked for response, with an option to add additional comments if appropriate. This paper focused on the evaluation of quantitative data. Questions about the number of endodontic treatments performed, type of treated teeth, students' learning, time spent on procedures, difficulties encountered, quality of endodontic treatment performed and characteristics of the technique employed aimed to determine the undergraduates' productivity and development in relation to their experience and number of semesters in the dental program.

A test-retest model was applied to assess answer variations from the same respondent at different times. Fifteen days after the first administration, the same questionnaire was administered a second time to 18 students, corresponding to $14.30 \%$ of the total sample. Agreement between responses was measured with a 
weighted kappa coefficient using QuickCalcs program (GraphPad Software Inc., San Diego, CA, USA).

The responses were selected on scales, and categorical responses were collated and analyzed using Statistical Package for the Social Sciences (SPSS) version 17.0 (SPSS Inc., Chicago, IL, USA). Descriptive statistics were obtained for all variables. Counts and percentages are reported for categorical variables, and mean and standard deviation are reported for continuous variables. The data obtained were subjected to a Kolmogorov-Smirnov test to determine their distribution. Absence of normal distribution $(p<0.001)$ led to the use of a non-parametric KruskalWallis test and the significance was set at $95 \%$ confidence level.

\section{RESULTS}

Test-retest agreement measured by the weighted kappa coefficient was 0.839 , with a confidence interval ranging from 0.666 to 0.883 , demonstrating a high degree of reproducibility of the answers and consequently a high degree of reliability.

There was a $91.3 \%$ rate of return for the questionnaires, so the sample consisted of 115 dental students. Table 1 displays the distribution of counts and frequencies of all categorical variables according to the group.

There were no statistically significant differences among the groups in gender distribution $(\mathrm{p}=0.834)$. Female gender predominated in all groups.

The means and standard deviations of the number of endodontic treatments performed by students in G1, G2, and G3 were $1.61(0.78), 1.34(0.52)$, and 3.00 (1.34), respectively. The statistical analysis showed significant differences between G3 and the other two groups ( $<<0.001)$. There was no statistically significant difference in the number of endodontic treatments performed by students in G1 and G2 ( $\mathrm{p}=0.580)$.

A total of 185 endodontic treatments were performed by the students who participated in this study. Only one student in G2 did not specify what kind of teeth he treated during the semester. The count and frequency distribution for the number of endodontic treatments performed and the kinds of treated teeth according to group is presented in Table 2. In G1, the majority of endodontic treatments were performed in maxillary incisors $(\mathrm{n}=32 ; 17.30 \%)$, followed by maxillary premolars $(\mathrm{n}=25 ; 13.52 \%)$. The mandibular molars were the most frequently treated teeth in G2 $(\mathrm{n}=40 ; 21.62 \%)$ and in $\mathrm{G} 3(\mathrm{n}=15 ; 8.11 \%)$, followed by maxillary molars $(\mathrm{n}=24 ; 12.97 \%$ and $\mathrm{n}=8 ; 4.32 \%)$.

Eighty-six students $(74.8 \%)$ considered their learning during endodontic treatments as good, 22 $(19.1 \%)$ as reasonable and $6(5.2 \%)$ as poor. Only one student in G1 (0.9\%) did not answer this question (Table 1). No statistically significant difference was noted among the groups $(\mathrm{p}=0.528)$, showing that students in G1, G2, and G3 had similar views of their learning during the endodontic treatments.

The time required to perform endodontic treatments was considered by the majority of the students as long $(\mathrm{n}=64 ; 55.7 \%)$, followed by appropriate $(n=38 ; 33 \%)$. Only G3 students considered the time spent as fast ( $\mathrm{n}=8 ; 7 \%)$. Five $\mathrm{G} 1$ students $(4.3 \%)$ did not answer this question (Table 1). There was a statistically significant difference when G1 and G2 were compared with G3 $(p<0.001)$, showing that the NiTi rotary endodontic instruments used by G3 students allowed them to perform treatments more quickly. There was no statistically significant difference between G1 and $\mathrm{G} 2(\mathrm{p}=0.549)$.

Seventy students $(60.9 \%)$ reported experiencing difficulties during the endodontic treatments. However, 45 students (39.1\%), 26 of whom belonging to G1, reported no difficulties (Table 1). A statistically significant difference in difficulties experienced during the endodontic treatment was found when G2 and G3 were compared with $\mathrm{G} 1(\mathrm{p}=0.048)$, and no statistically significant difference was found when G2 and G3 were compared $(\mathrm{p}=0.362)$.

Considering the quality of endodontic treatment performed, 97 students $(84.3 \%)$ classified their treatments as good. Seventeen students (14.8\%), 13 of whom were in $\mathrm{G} 2$, classified their treatments as adequate and only one student in G1 (0.9\%) classified them as bad (Table 1). A statistical difference was found when $\mathrm{G} 1$ and $\mathrm{G} 2$ were compared $(\mathrm{p}=0.045)$. No significant difference was detected between G1 and G3 $(p=0.283)$ or $\mathrm{G} 2$ and $\mathrm{G} 3(\mathrm{p}=0.68)$.

Fifty-eight students (50.4\%) attributed positive characteristics to the technique they used during endodontic treatment. Twenty-nine students $(25.3 \%)$ did not answer this question. Only G1 and G2 students reported negative characteristics or a combination of positive and negative characteristics (Table 1), but there were no statistically significant differences among the groups on this question $(\mathrm{p}=0.560)$. 
Table 1. Distribution of counts and frequencies for all categorical variables according to the group.

\begin{tabular}{|c|c|c|c|c|c|c|c|c|}
\hline \multirow{3}{*}{ Categorical variable } & \multicolumn{6}{|c|}{ Group } & \multirow{2}{*}{\multicolumn{2}{|c|}{ Total }} \\
\hline & \multicolumn{2}{|c|}{ G1 } & \multicolumn{2}{|c|}{ G2 } & \multicolumn{2}{|c|}{ G3 } & & \\
\hline & $\mathrm{n}$ & $\%$ & $\mathrm{n}$ & $\%$ & $\mathrm{n}$ & $\%$ & $\mathrm{n}$ & $\%$ \\
\hline \multicolumn{9}{|l|}{ Gender } \\
\hline Male & 18 & 15.6 & 16 & 13.9 & 4 & 30.5 & 38 & 33 \\
\hline Female & 33 & 28.7 & 37 & 32.2 & 7 & 60.1 & 77 & 67 \\
\hline Total & 51 & 44.3 & 53 & 46.1 & 11 & 90.6 & 115 & 100 \\
\hline \multicolumn{9}{|c|}{ Number of endodontic treatments } \\
\hline 1 & 26 & 22.6 & 36 & 31.3 & 2 & 10.7 & 64 & 55.7 \\
\hline 2 & 21 & 18.3 & 16 & 13.9 & 2 & 10.7 & 39 & 33.9 \\
\hline 3 & 3 & 20.6 & 1 & 00.9 & 2 & 10.7 & 6 & 5.2 \\
\hline 4 or more & 1 & 00.9 & 0 & 0 & 5 & 40.3 & 6 & 50.2 \\
\hline Total & 51 & 44.3 & 53 & 46.1 & 11 & 90.6 & 115 & 100 \\
\hline \multicolumn{9}{|l|}{ Learning during treatment } \\
\hline Good & 40 & 34.8 & 37 & 32.2 & 9 & 70.8 & 86 & 74.8 \\
\hline Reasonable & 9 & 70.8 & 12 & 10.4 & 1 & 00.9 & 22 & 19.1 \\
\hline $\mathrm{Bad}$ & 1 & 00.9 & 4 & 30.5 & 1 & 00.9 & 6 & 50.2 \\
\hline Did not answer & 1 & 00.9 & 0 & 0 & 0 & 0 & 1 & 1 \\
\hline Total & 51 & 44.3 & 53 & 46.1 & 11 & 90.6 & 115 & 100 \\
\hline \multicolumn{9}{|l|}{ Time spent } \\
\hline Fast & 0 & 0 & 0 & 0 & 8 & 7 & 8 & 7 \\
\hline Appropriate & 21 & 18.3 & 15 & 13 & 2 & 10.7 & 38 & 33 \\
\hline Long & 25 & 21.7 & 38 & 33 & 1 & 00.9 & 64 & 55.7 \\
\hline Did not answer & 5 & 40.3 & 0 & 0 & 0 & 0 & 5 & 40.3 \\
\hline Total & 51 & 44.3 & 53 & 46.1 & 11 & 90.6 & 115 & 100 \\
\hline \multicolumn{9}{|l|}{ Difficulties } \\
\hline Yes & 25 & 21.7 & 36 & 31.3 & 9 & 70.8 & 70 & 60.9 \\
\hline No & 26 & 22.6 & 17 & 14.8 & 2 & 10.7 & 45 & 39.1 \\
\hline Total & 51 & 44.3 & 53 & 46.1 & 11 & 90.6 & 115 & 100 \\
\hline \multicolumn{9}{|l|}{ Quality of treatment } \\
\hline Good & 46 & 40 & 40 & 34.8 & 11 & 90.6 & 97 & 84.3 \\
\hline Adequate & 4 & 30.5 & 13 & 11.3 & 0 & 0 & 17 & 14.8 \\
\hline $\mathrm{Bad}$ & 1 & 00.9 & 0 & 0 & 0 & 0 & 1 & 00.9 \\
\hline Total & 51 & 44.3 & 53 & 46.1 & 11 & 90.6 & 115 & 10.0 \\
\hline \multicolumn{9}{|c|}{ Characteristics of technique employed } \\
\hline Positive & 26 & 22.6 & 24 & 20.9 & 8 & 70.0 & 58 & 50.4 \\
\hline Positive and negative & 5 & 40.3 & 7 & 60.1 & 0 & 0 & 12 & 10.4 \\
\hline Negative & 7 & 60.1 & 9 & 70.8 & 0 & 0 & 16 & 13.9 \\
\hline Did not answer & 13 & 11.3 & 13 & 11.3 & 3 & 20.6 & 29 & 25.3 \\
\hline Total & 51 & 44.3 & 53 & 46.1 & 11 & 90.6 & 115 & 100 \\
\hline
\end{tabular}

G1: students who had treated straight canals with SS hand instruments. G2: students who had treated curved canals with SS hand instruments. G3: students who had treated both straight and curved canals with NiTi rotary instruments. 
Table 2. Distribution of counts and frequencies of number of endodontic treatments performed by the students and type of endodontically treated teeth, according to the group.

\begin{tabular}{|c|c|c|c|c|c|c|c|c|}
\hline \multirow{2}{*}{ Tooth type } & \multicolumn{2}{|c|}{ G1 } & \multicolumn{2}{|c|}{ G2 } & \multicolumn{2}{|c|}{ G3 } & \multicolumn{2}{|c|}{ Total } \\
\hline & $\mathrm{N}$ & $\%$ & $\mathrm{~N}$ & $\%$ & $\mathrm{~N}$ & $\%$ & $\mathrm{n}$ & $\%$ \\
\hline \multicolumn{9}{|l|}{ Maxillary arch } \\
\hline Central incisor & 18 & 90.73 & 0 & 0 & 1 & 00.54 & 19 & 10.27 \\
\hline Lateral incisor & 14 & 70.57 & 1 & 00.54 & 2 & 10.08 & 17 & 90.19 \\
\hline Canine & 4 & 20.16 & 0 & 0 & 0 & 0 & 4 & 20.16 \\
\hline First premolar & 14 & 70.57 & 1 & 00.54 & 2 & 10.08 & 17 & 90.19 \\
\hline Second premolar & 11 & 50.95 & 0 & 0 & 4 & 20.16 & 15 & 80.11 \\
\hline First molar & 0 & 0 & 21 & 11.35 & 5 & 20.70 & 26 & 14.05 \\
\hline Second molar & 0 & 0 & 3 & 10.62 & 3 & 10.62 & 6 & 30.24 \\
\hline Total & 61 & 32.98 & 26 & 14.05 & 17 & 90.18 & 104 & 56.21 \\
\hline \multicolumn{9}{|l|}{ Mandibular arch } \\
\hline Central incisor & 4 & 20.16 & 1 & 00.54 & 0 & 0 & 5 & 20.70 \\
\hline Lateral incisor & 1 & 00.54 & 0 & 00 & 0 & 0 & 1 & 00.54 \\
\hline Canine & 6 & 30.24 & 0 & & 0 & 0 & 6 & 30.24 \\
\hline First premolar & 6 & 30.24 & 0 & 0 & 0 & 0 & 6 & 30.24 \\
\hline Second premolar & 5 & 20.70 & 0 & 0 & 1 & 00.54 & 6 & 30.24 \\
\hline First molar & 0 & 0 & 29 & 15.67 & 12 & 60.49 & 41 & 22.16 \\
\hline Second molar & 0 & 0 & 11 & 50.95 & 3 & 10.62 & 14 & 70.57 \\
\hline Not specified* & 0 & 0 & 2 & 10.08 & 0 & 0 & 2 & 10.08 \\
\hline Total & 22 & 11.88 & 43 & 23.24 & 16 & 80.65 & 81 & 43.79 \\
\hline
\end{tabular}

*One student reported that he performed two endodontic treatments, but he did not specify the type of teeth. G1: students who had treated straight canals with SS hand instruments. G2: students who had treated curved canals with SS hand instruments. G3: students who had treated both straight and curved canals with NiTi rotary instruments.

\section{DISCUSSION}

Questionnaires have proven to be an effective method for capturing data related to educational issues. This study had a questionnaire response rate of $91.3 \%$, which is adequate to provide meaningful data. However, great variability $(63 \%$ to $100 \%)$ in return rates have been reported in other studies $(3,5,8,14,15)$. This variability may occur because of the way the questionnaire is presented (i.e., e-mail, letter, in the classroom). For this study, the questionnaire was administered to undergraduate students during their final examinations, in the classroom. The high response rate may be attributed to this fact.

The majority of students in all three groups were female. This result concurs with other studies (14) showing a trend toward more female than male students at dental schools. Sofola and Jeboda (3), on the other hand, found a balance of gender among Nigerian dental students.

The use of NiTi rotary instruments significantly favored the execution of more endodontic treatments. Students who used NiTi rotary instruments (those in G3) performed more treatments than students who used stainless steel hand files (those in G1 and G2). Many authors have reported the advantages of rotary 
preparation with NiTi instruments over hand preparation for both experienced and inexperienced operators. Students have obtained significantly better results in root canal preparation with NiTi rotary instruments, which allow them to prepare curved root canals with less transportation and greater conservation of tooth structure compared to canals prepared with stainless steel hand instruments $(7,10)$. This technology has been proven significantly faster than the hand technique, with a potential effect on the clinical treatment time $(7,8,10)$. The reduced time required to perform endodontic treatments was observed in the present study. Only students in G3 considered the time required to perform endodontic treatment as fast, while the majority of students in G1 and G2 considered it long. The main factors that influenced the length of time spent during endodontic treatments, according to the students, are non-attendance of patients, lack of clinical experience and difficulties with the exposure of radiographs (16). During the fifth semester, G1 students have their first contact with the Endodontics discipline (theory and preclinical and clinical training). Even shaping singlerooted and/or two-rooted teeth with straight canals can present difficulties inherent in a new training, such as achieving adequate isolation and open access, determining working length, and preparing and filling the canal (5). During the sixth semester, G2 students perform endodontic treatments in multi-rooted teeth, which are considered more difficult by many undergraduate students because of their anatomic complexity, with different angles and radius of canal curvature (5). These facts, plus the SS instruments employed, result in more time and consequently, more sessions to perform endodontic treatments. By their eighth semester, G3 students have already completed Endodontics I and II disciplines. Consequently, they have greater ability and more endodontic experience than students in the other groups. These facts, plus the use of NiTi rotary instruments, allow them to complete treatments with less time and fewer sessions, which increase the number of endodontic treatments they are able to perform.

The majority of students considered their learning during endodontic treatment as good. The main causes cited by students that may have affected their learning during endodontic treatments are patients' nonattendance or delays; amount of clinical training; teacher orientation; difficulties or lack of clinical experience; the number of endodontic treatments performed; and time spent during endodontic treatments (16). However, despite the lack of statistically significant difference, some students, essentially those in G1 and G2, classified their learning as reasonable or bad, indicating some dissatisfaction. At UFMG, all Endodontics disciplines require $60 \mathrm{~h}$ of practical training per semester $(4 \mathrm{~h}$ per week). Preclinical training, using extracted teeth, takes place before clinical training with patients. During the fifth semester, the students (G1) have $16 \mathrm{~h}$ of preclinical training and $44 \mathrm{~h}$ for clinical practice with patients. During the sixth and eighth semesters, G2 and G3 students have $8 \mathrm{~h}$ of preclinical training and $52 \mathrm{~h}$ for clinical practice with patients. However, because the students in G1 and G2 work in operator/assistant pairs during clinical treatment, each student meets a patient every 15 days, thus the student's hands-on experience with patients is reduced by half. Dental students commonly perceived clinical experience to be the most important aspect of their education (17-19). They want as much exposure to patients and as much experience in the clinical setting as feasible $(18,19)$. They feel less prepared for exercises that are perceived to be more difficult, such as endodontic treatments. The limited time for preclinical and clinical training in Endodontics can result in low self-confidence during clinical practice. Students' self-confidence can be increased by greater exposure to procedures and patients $(2,5)$. These facts could explain the dissatisfaction noted among some G1 and $\mathrm{G} 2$ students about their learning during endodontic treatment.

Difficulties during endodontic treatments were reported by a large number of $\mathrm{G} 2$ and G3 students, while half of the G1 students reported no difficulties. G2 and G3 students performed endodontic treatments of molars, which have a complex anatomy and curvatures while G1 students performed endodontic treatment of straight canals. Despite the difficulties found during endodontic treatment, the students regarded their treatments as good. The quality attributed to the endodontic treatments performed by the students was related mainly to radiographic analysis and procedural errors (16). Some students, the majority of whom were from G2, classified their treatments as adequate and only one student in G1 $(0.9 \%)$ classified his/her treatment as bad. Radiographic studies used to evaluate the technical quality of root fillings performed by undergraduate students showed the highest percentage of adequate fillings in maxillary incisors, and the highest percentage of inadequate fillings in molars (20-23). This may be due to problems such as ledge formation or the blockage of canals by dentine 
during instrumentation of curved canals (21), and could explain the obtained results. However, Moussa-Badran et al. (23) attributed the poor technical quality of root fillings performed by undergraduate students to the time constraints of pre-clinical training in Endodontics, with consequent concerns about competence during the clinical practice. On the other hand, Er et al. (22) believe that the need to treat a high number of teeth in a limited amount of time might be an important factor related to the generally poor quality of root fillings performed by undergraduate students. The endodontic teaching program varies from dental school to dental school in relation to the number of hours devoted to theory and preclinical and clinical training $(2,17,21-23)$. Many schools consider preclinical education essential for teaching manual skills. In those cases, theory may be underemphasized $(2,15)$. However, it is very important that students have the opportunity to apply educational theory in dental clinical practice and learn to solve problems related to patient care (17).

Regardless of the instruments employed, all groups used crown-down technique. Only students who used SS hand instruments (G1 and G2) to shape the root canals attributed negative characteristics (such as "complex", "boring" and "laborious") to the technique employed. On the other hand, students who used NiTi rotary instruments (G3) attributed positive characteristics ("easy", "fast" and "efficient") to the technique employed. Arbab-Chirani and Vulcain (8) observed positive perceptions from students using rotary NiTi instruments. The students classified these instruments as easier learning to use, more rapid, safer and more effective for clinical use, and considered these endodontic techniques generally better than manual root canal preparations. The same results were obtained by Sonntag et al. (10).

The NiTi rotary technique should be integrated into undergraduate dental education, because it seems advisable for practical endodontic training to initiate with rotary technique. This would allow students gain confidence prior to performing more complex manual techniques by introducing a simple working sequence that would provide an initial sense of achievement $(11,20)$. This technique could be safely introduced into undergraduate dental curriculum, resulting in a substantial improvement in the quality of root canal preparation, particularly by inexperienced students $(7,20)$. It could also have an important impact on the efficiency and outcome of endodontic treatments.
Despite a marked decline in the prevalence of caries in several countries, the expected corresponding decrease in the frequency of endodontic treatment has not been observed. Dental caries and their effects continue to be responsible for the majority of root canal treatments $(24,25)$. Moreover, the reduced tooth extraction rate consequently puts more teeth at risk for pulpal injury (25). In this study, mandibular molars were more often treated endodontically, followed by maxillary incisors, according to Quadros et al. (24). The high incidence of endodontic treatment in mandibular molars may be due to the fact that these are the first permanent teeth to erupt in the oral cavity and therefore are more susceptible to dental caries. The incorporation of rotary NiTi instruments by dental schools would allow endodontic treatments to be performed more quickly, which could impact positively the demand for endodontic treatment, increase resolution in public clinics and reduce waiting time for treatment.

Student feedback is a fundamental part of the assessment and/or evaluation of teaching processes. It allows students to express their views, provides valuable information about their learning and suggests necessary curriculum modifications $(1,2)$.

Despite the limitations of this study, such as the small number of students evaluated, the feedback obtained showed that NiTi rotary instruments should be included in dental curriculum to increase students' self-confidence by using a simple working sequence and to increase the number of assisted patients.

\section{RESUMO}

Este estudo avaliou a percepção de alunos de graduação de uma Faculdade de Odontologia brasileira sobre os tratamentos endodônticos realizados utilizando instrumentos rotatórios de níquel-titânio (NiTi) e manuais de aço-inoxidável. Os dados foram coletados por meio de um questionário semi-estruturado aplicado aos alunos de graduação matriculados nas disciplinas de Endodontia. Os estudantes foram divididos em 3 grupos; G1; estudantes que realizaram tratamentos endodônticos em dentes com canais retos utilizando instrumentos manuais de aço-inoxidável; $\mathrm{G} 2$, estudantes que realizaram tratamentos endodônticos em dentes com canais curvos utilizando instrumentos manuais de aço-inoxidável e G3, estudantes que realizaram tratamentos endodônticos em dentes com canais retos e curvos utilizando instrumentos rotatórios de NiTi. O número de tratamentos endodônticos realizados, tipos de dentes tratados, aprendizado dos estudantes, tempo gasto, dificuldades encontradas, qualidade dos tratamentos realizados e características das técnicas de instrumentação utilizadas foram analisadas. Houve uma taxa de retorno de $91,3 \%$ dos questionários. Molares inferiores foram os dentes mais tratados, seguidos dos incisivos superiores. $\mathrm{O}$ 
teste de Kruskal-Wallis não mostrou diferenças no aprendizado $(p=0,528)$ ou nas características das técnicas utilizadas $(p=0,560)$ entre os três grupos. Estudantes do G3 realizaram um maior número de tratamentos endodônticos $(\mathrm{p}<0,001)$ e em menor tempo $(p<0,001)$ que os estudantes do G1 e G2. Dificuldades foram relatadas principalmente pelos alunos do $\mathrm{G} 2$ e G3 em comparação ao $\mathrm{G} 1(\mathrm{p}=0,048)$. A qualidade dos tratamentos endodônticos relatada foi diferente apenas entre G1 e G2 (p=0,045). O uso dos instrumentos rotatórios de NiTi deveria ser incluído no currículo da graduação em Odontologia, contribuindo para o aumento de pacientes atendidos e, consequentemente, para o aprimoramento da experiência clínica dos alunos.

\section{ACKNOWLEDGEMENTS}

This study was supported by Fundação de Amparo à Pesquisa do Estado de Minas Gerais (FAPEMIG), Brazil, Conselho Nacional de Desenvolvimento Científico e Tecnológico (CNPq), Brazil, and Coordenação de Aperfeiçoamento de Pessoal de Nível Superior (CAPES), Brazil.

\section{REFERENCES}

1. Oliver R, Kersten H, Vinkka-Puhakka H, Alpasan G, Bearn D, Cema I, et al.. Curriculum structure: principles and strategy. Eur J Dent Educ 2008;12:74-84.

2. Lanning SK, Wetzel AP, Baines MB, Ellen Byrne B. Evaluation of a revised curriculum: a four-year qualitative study of student perceptions. J Dent Educ 2012;76:1323-1333.

3. Sofola OO, Jeboda SO. Perceived sources of stress in Nigerian dental students. Eur J Dent Educ 2006;10:20-23.

4. Divaris K, Barlow PJ, Chendea SA, Cheong WS, Dounis A, Dragan IF, et al.. The academic environment: the students' perspective. Eur J Dent Educ 2008;12:120-130.

5. Rolland S, Hobson R, Hanwell S. Clinical competency exercises: some student perceptions. Eur J Dent Educ 2007;11:184-191.

6. Walia H, Brantley WA, Gerstein HN. An initial investigation of the bending and torsional properties of nitinol root canal files. J Endod 1988;14:3463-3451.

7. Peru M, Peru C, Mannocci F, Sherriff M, Buchanan LS, Pitt Ford TR. Hand and nickel-titanium root canal instrumentation performed by dental students: a micro-computed tomographic study. Eur J Dent Educ 2006;10:52-59.

8. Arbab-Chirani R, Vulcain JM. Undergraduate teaching and clinical use of rotary nickel-titanium endodontic instruments: a survey of French dental schools. Inter Endod J 2004;37:320-324.

9. Parashos P, Messer HH. The diffusion of innovation in dentistry: a review using rotary nickel-titanium technology as an example. Oral Surg Oral Med Oral Pathol Oral Radio Endod 2006;101:395401.
10. Sonntag D, Delschen S, Stachniss V. Root canal shaping with manual and rotary NiTi files performed by students. Inter Endod J 2003;36:715-723.

11. Marshal FJ, Pappin JA. A crown-down pressureless preparation root canal enlargement technique. Portland: Oregon. Health Science University, 1980.

12. Buchanan LS. Management of the curve root canal. J Calif Dent Assoc 1989;17:18-27.

13. Ruddle CJ. The ProTaper Endodontic System: geometries, features, and guidelines for use. Dent Today 2001;20:60-67.

14. Machado-Carvalhais HP, Ramos-Jorge ML, Auad SM, Martins LHPM, Paiva SM, Pordeus IA. Occupational exposure to potentially infectious biological material in a dental teaching environment. J Dent Educ 2008;72:1201-1208.

15. Sonntag D, Bärwald R, Hülsmann M, Stachniss V. Pre-clinical Endodontics: a survey amongst German dental schools. Inter Endod J 2008;41:863-868.

16. Seijo MOS, Ferreira EF, Ribeiro Sobrinho AP, Paiva SM, Martins RM. Learning experience in Endodontics: Brazilian student's perceptions. J Dent Educ. J Dent Educ (in press).

17. Gerzina TM, McLean T, Fairley J. Dental clinical teaching: perceptions of students and teachers. J Dent Educ 2005;69:13771384.

18. Cardall WR, Rowan RC, Bay C. Dental education from the students' perspective: curriculum and climate. J Dent Educ 2008;72:600-609.

19. Shelty VB, Shirahatti RV, Pawar P. Students perceptions of their education on graduation from a dental school in India. J Dent Educ 2012;76:1520-1526.

20. Alencar AHG, Dummer PMH, Oliveira HCM, Pécora JD, Estrela C. Procedural errors during root canal preparation using rotary $\mathrm{NiTi}$ instruments detected by periapical radiography and cone beam computed tomography. Braz Dent J 2010;21:543-549.

21. Lynch CD, Burke FM. Quality of root canal fillings performed by undergraduate dental students on single-rooted teeth. Eur J Dent Educ 2006;10:67-72.

22. Er O, Sagsen B, Maden M, Cinar S, Kahraman Y. Radiographic technical quality of root fillings performed by dental students in Turkey. Inter Endod J 2006;39:867-872.

23. Moussa-Badran S, Roy B, Bessart du Parc AS, Bruyant M, Lefevre B, Maurin JC. Technical quality of root fillings performed by dental students at the dental teaching centre in Reims, France. Inter Endod J 2008;41:679-684.

24. Quadros ID, Gomes BPFA, Zaia AA, Ferraz CCR, Souza-Filho FJ. Evaluation of endodontic treatments performed by students in a Brazilian dental school. J Dent Educ 2005;69:1161-1170.

25. Reit C, Bergenholtz G, Caplan D, Molander A. The effect of educational intervention on the adoption of nickel-titanium rotary instrumentation in a public dental service. Inter Endod J 2007; $40: 268-274$. 